\title{
MICROSATELLITE DNA POLYMORPHISM AND ITS USEFULNESS FOR PEDIGREE VERIFICATION IN SIMMENTAL CATTLE FROM SERBIA
}

\author{
STEVANOVIĆ JEVROSIMA, STANIMIROVIĆ Z, DIMITRIJEVIĆ V, STOJIĆ V, FRATRIĆ NATALIJA \\ and LAZAREVIĆ M \\ Faculty of Veterinary Medicine, University of Belgrade, Serbia \\ (Received $12^{\text {th }}$ July)
}

The polymorphism of 11 microsatellite DNA markers (TGLA227, BM2113, TGLA53, ETH10, SPS115, TGLA126, TGLA122, INRA23, ETH3, ETH225, BM1824) was analysed in order to assess the usefulness of these markers for pedigree verification in the Serbian population of Simmental cattle. A total of 86 animals were involved in the study. Genomic DNA was extracted from sperm and blood and amplified in a multiplex PCR using primers from the commercial "StockMarks for Cattle ${ }^{\circledR}$ Bovine Genotyping Kit". Analyses were done with automated DNA sizing technology. A total of 92 alleles were detected. The mean number of alleles $\left(n_{A}\right)$ per locus was 8.364 , the mean value of polymorphism information content (PIC) was 0.73 , and the mean frequency of the most frequent allele (FNA) was 0.372. The most polymorphic microsatellite loci were: TGLA53 (14 alleles, $P I C=0.88, F N A=0.235), T G L A 227$ (11 alleles, $P I C=0.82, F N A=0.274)$, INRA23 (11 alleles, PIC=0.86, FNA=0.167), BM2113 (9 alleles, $P I C=0.84, F N A=0.330)$. Both combined power of discrimination (CPD) and combined power of exclusion (CPE) for the whole set of studied markers were 0.999. In conclusion, the polymorphism of 11 microsatellite DNA markers observed in this study indicate its usefulness for paternity testing and pedigree verification in Simmental cattle from Serbia. Serbia

Key words: cattle, microsatellites, pedigree, polymorphism,

\section{INTRODUCTION}

Microsatellite DNA markers are excellent genetic markers because of their high polymorphism and abundant distribution throughout the genome. They are generally polyallelic, and their number is almost unlimited. Nowadays, microsatellite DNA markers are used for paternity testing and pedigree verification of livestock, including cattle (Curi and Lopes, 2002; Radko, 2008; Rehout et al., 2006; Cervini et al., 2006; Tian et al., 2008; Ozkan et al., 2009; Carolino et al., 2009). Many authors used microsatellites for the analyses of genetic diversity in 
cattle (Čítek and Rehout, 2001; Čítek et al., 2006; Grzybowski and Prusak, 2004a, 2004b; Radko et al., 2005; Zhou et al., 2005; Czernekova et al., 2006; ZatonDobrowolska et al., 2007).

Paternity testing using microsatellites in cattle has significant advantages over the traditional methods using blood groups and protein polymorphism. The main disadvantage of traditional methods is the relatively low precision since it does not enable always the exclusion of a putative sire, even if that putative sire is not the real parent. Consequently, high frequency of incorrect cattle paternity was obtained with these methods, and the proportion of errors in sire identification ranged from few percent to as much as $23 \%$ (Bovenhuis and van Arendonk, 1991). Another disadvantage is that blood and protein analyses can not be performed retrospectively, e.g., after a sire is dead. On the other hand, the accuracy of the parentage test using microsatellite DNA markers is much higher, as the probability of detecting mistaken paternity or maternity is a function of the polymorphism of genotyped loci (Ron et al., 1996). In addition, any sample from an animal (e.g., hair, milk, saliva, semen) can be used, as long as it contains DNA, so genotyping can be done retrospectively, e.g., after a sire is dead, if any sample is stored.

Pedigree verification through paternity testing is necessary if we want to achieve optimal genetic progress in cattle breeding. Misidentification of parentage can lead to breeding inaccuracy, causing great financial losses in herd management and in the beef industry (Cervini et al., 2006). In conservation programs, pedigree recording is important for the control of inbreeding and loss of genetic variability and fitness (Carolino et al., 2006).

Microsatellite markers that are characterized by high polymorphism, wellbalanced frequency of alleles, high values of polymorphism information content, expected heterozygosity and power of discrimination and probability of exclusion, are considered usefull for pedigree verification (Radko, 2008; Ozkan et al., 2009). Combined power of discrimination for all analysed loci must be greater than 0.999 for the acceptable level of the microsatellite loci in parentage testing (Vankan and Faddy, 1999; Pérez-Miranda et al., 2005).

Polymorphism of 11 microsatellite markers (TGLA227, BM2113, TGLA53, ETH10, SPS115, TGLA126, TGLA122, INRA23, ETH3, ETH225, BM1824) recommended by the International Society for Animal Genetics (ISAG) was already evaluated for parentage verification in other Simmental breeds, in Czech Pied and Slovakian Pied (Czerneková et al., 2006) and in Simmental cattle from Poland (Janik et al., 2001; Choroszy et al., 2006). However, in cattle raised in Serbia, there were no investigations of microsatellite DNA polymorphism and no report about successful establishment of paternity identification. There were only cytogenetic investigations in the past (Soldatović et al., 1993, 1994a, 1994b; Vučinić et al., 1996).

The aim of this study was to analyse the polymorphism of 11 microsatellite markers from ISAG panel (TGLA227, BM2113, TGLA53, ETH10, SPS115, TGLA126, TGLA122, INRA23, ETH3, ETH225, BM1824) and to evaluate their usefulness for pedigree verification in the Serbian population of Simmental cattle. 


\section{MATERIAL AND METHODS}

Sperm or blood samples were taken from 86 heads of Simmental cattle from Serbia. Experiments performed comply with current laws and written consent of the Scientific Ethic Committee and were done with the permission of the Local Ethic Commitee of the Faculty of Veterinary Medicine, University of Belgrade. Genomic DNA from sperm and blood was isolated with "DNeasy ${ }^{\circledR}$ Blood \& Tissue Kit" (Qiagen, Valencia, CA) and kept frozen at $-18^{\circ} \mathrm{C}$ until further processing. Microsatellites were amplified using the "StockMarks for Cattle ${ }^{\circledR}$ Bovine Genotyping Kit" (Applied Biosystems Inc., Foster City, CA). Multiplex amplifications were performed in a programmable thermal cycler MultiGene Gradient (Labnet International Inc) in $15 \mu \mathrm{L}$ volumes containing $1 \mu \mathrm{L}$ of DNA, 3.0 $\mu \mathrm{L}$ of StockMarks buffer, $4.0 \mu \mathrm{L}$ of dNTP mix (1.25 mM of each dNTP), $5.5 \mu \mathrm{L}$ of amplification primer mix, $0.5 \mu \mathrm{L}$ of AmpliTaq Gold DNA Polymerase (Applied Biosystems Inc., Foster City, CA), and $1.0 \mu \mathrm{L}$ of deionized water. The sample was then amplified using PCR with the following program: the reactions were heated for $15 \mathrm{~min}$ at $95^{\circ} \mathrm{C}$ followed by 31 cycles of denaturation $\left(94^{\circ} \mathrm{C}, 45 \mathrm{~s}\right)$, annealing $\left(61^{\circ} \mathrm{C}, 45 \mathrm{~s}\right)$, and extension $\left(72^{\circ} \mathrm{C}, 60 \mathrm{~s}\right)$. A final extension was carried out at $72^{\circ} \mathrm{C}$ for $1 \mathrm{~h}$ and then at $25^{\circ} \mathrm{C}$ for $2 \mathrm{~h}$.

The fluorescent labeled PCR products were submitted to fragments analysis by capillary electrophoresis, with an automated sequencer ABI PRISM 310 (Applied Biosystems), using the GeneScan-350 ROX ${ }^{\circledR}$ Size Standard (Applied Biosystems), according to manufacturer's specifications. Results were read and interpreted using GeneScan ${ }^{\circledR}$ and Genotyper ${ }^{\circledR}$ software, respectively.

Eleven microsatellites (TGLA227, BM2113, TGLA53, ETH10, SPS115, TGLA126, TGLA122, INRA23, ETH3, ETH225, BM1824) recommended by ISAG for cattle paternity testing (ISAG Conference, 2008) were analysed in this study. Microsatellite markers are usefull in parentage testing and pedigree verification if they are highly informative. All measures of informativeness were estimated for the chosen markers of ISAG panel. The number of alleles $\left(n_{A}\right)$, frequency of the most frequent allele (FNA), observed and expected heterozygosity ( $\mathrm{Ho}$ and $\mathrm{He}$ ), polymorphism information content (PIC), power of discrimination (PD) and power of exclusion (PE) were calculated for each microsatellite marker. Combined power of discrimination (CPE) and combined power of exclusion (CPE) were calculated for the whole set of studied markers. Allele frequencies, PIC, PD and PE were determined by the PowerStatsV12 freeware, Promega Corporation, USA. Ho and $\mathrm{He}$, as well as calculations for Hardy-Weinberg Equilibrium were performed in Arlequine ver. 3.1 (Excoffier et al., 2006).

\section{RESULTS}

In the studied population of Simmental cattle from Serbia, the $\mathrm{n}_{\mathrm{A}}$ per locus ranged from 6 (SPS115, TGLA126, ETH3, BM1824) to 14 (TGLA53), the mean $n_{A}$ per locus was 8.364, and a total number of alleles was 92 . The mean frequency of the most frequent allele (FNA) was 0.372 (Table 1). PIC values ranged from 0.58 to 0.88 with mean value of 0.73 (Table 2 ). High number of alleles and PIC values were 
observed for TGLA53 ( 14 alleles, PIC $=0.88$ ), TGLA227 ( 11 alleles, PIC=0.82), INRA23 ( 11 alleles, PIC=0.86), BM2113 (9 alleles, $\mathrm{PIC}=0.84)$ and TGLA122 (9 alleles, $\mathrm{PIC}=0.70$ ). In addition, FNA of these loci was well below 0.5 , with lowest values in INRA23 (0.167), TGLA53 (0.235), TGLA227 (0.274) and BM2113 (0.330), thus are the most polymorphic and most informative markers among tested loci in this study (Table 1). These four loci (TGLA53, TGLA227, INRA23 and BM2113) showed also highest values of $\mathrm{He}$ and PD (Table 2). Although all loci showed PIC values over 0.5 (Table 2), the polymorphism and informativeness of ETH10 and SPS115 is lower than other loci because their FNA values were higher than 0.5 (Table 1). Both CPD and CPE were 0.999 (Table 2). In addition, Ho ranged from 0.452 (TGLA122) to 0.774 (INRA23), with mean value of 0.662 , whilst He varied from 0.557 (ETH10) to 0.893 (TGLA53), with an average of 0.753 . Except loci TGLA227, TGLA53 and TGLA122 that were significantly deviated from HardyWeinberg equilibrium $(p<0.05)$, other loci were conformed to Hardy-Weinberg equilibrium.

Table 1. Polymorphism of the 11 microsatellite markers in the Serbian population of Simmental cattle

\begin{tabular}{|c|c|c|c|c|c|}
\hline $\begin{array}{c}\text { Microsatellite } \\
\text { marker }\end{array}$ & $\mathrm{n}_{\mathrm{A}}$ & $\begin{array}{l}\text { Allele size } \\
\text { range (bp) }\end{array}$ & Alleles & $\begin{array}{c}\text { Allele } \\
\text { frequency }\end{array}$ & FNA \\
\hline \multirow[t]{11}{*}{ TGLA227 } & \multirow[t]{11}{*}{11} & \multirow[t]{11}{*}{$78-114$} & 78 & 0.032 & \multirow[t]{11}{*}{0.274} \\
\hline & & & 80 & 0.274 & \\
\hline & & & 82 & 0.032 & \\
\hline & & & 86 & 0.016 & \\
\hline & & & 88 & 0.097 & \\
\hline & & & 90 & 0.194 & \\
\hline & & & 92 & 0.097 & \\
\hline & & & 94 & 0.032 & \\
\hline & & & 96 & 0.129 & \\
\hline & & & 98 & 0.081 & \\
\hline & & & 114 & 0.016 & \\
\hline \multirow[t]{9}{*}{ BM2113 } & \multirow[t]{9}{*}{9} & \multirow[t]{9}{*}{$122-142$} & 122 & 0.070 & \multirow[t]{9}{*}{0.330} \\
\hline & & & 124 & 0.133 & \\
\hline & & & 128 & 0.330 & \\
\hline & & & 130 & 0.084 & \\
\hline & & & 132 & 0.150 & \\
\hline & & & 134 & 0.033 & \\
\hline & & & 136 & 0.100 & \\
\hline & & & 140 & 0.033 & \\
\hline & & & 142 & 0.067 & \\
\hline
\end{tabular}


Acta Veterinaria (Beograd), Vol. 59. No. 5-6, 621-631, 2009.

Stevanović Jevrosima et al.: Microsatellite DNA polymorphism and

its usefulness for pedigree verification in Simmental cattle from Serbia

\begin{tabular}{|c|c|c|c|c|c|}
\hline \multicolumn{6}{|c|}{ Cont. Table 1.} \\
\hline \multirow[t]{14}{*}{ TGLA53 } & \multirow[t]{14}{*}{14} & \multirow[t]{14}{*}{$150-184$} & 150 & 0.103 & \multirow[t]{14}{*}{0.235} \\
\hline & & & 154 & 0.029 & \\
\hline & & & 156 & 0.103 & \\
\hline & & & 158 & 0.029 & \\
\hline & & & 160 & 0.059 & \\
\hline & & & 162 & 0.044 & \\
\hline & & & 164 & 0.235 & \\
\hline & & & 166 & 0.118 & \\
\hline & & & 168 & 0.088 & \\
\hline & & & 170 & 0.059 & \\
\hline & & & 172 & 0.015 & \\
\hline & & & 174 & 0.059 & \\
\hline & & & 182 & 0.044 & \\
\hline & & & 184 & 0.015 & \\
\hline \multirow[t]{7}{*}{ ETH10 } & \multirow[t]{7}{*}{7} & \multirow[t]{7}{*}{$206-220$} & 206 & 0.020 & \multirow[t]{7}{*}{0.600} \\
\hline & & & 210 & 0.060 & \\
\hline & & & 212 & 0.040 & \\
\hline & & & 214 & 0.600 & \\
\hline & & & 216 & 0.120 & \\
\hline & & & 218 & 0.100 & \\
\hline & & & 220 & 0.060 & \\
\hline \multirow[t]{6}{*}{ SPS115 } & \multirow[t]{6}{*}{6} & \multirow[t]{6}{*}{$242-254$} & 242 & 0.515 & \multirow[t]{6}{*}{0.515} \\
\hline & & & 244 & 0.015 & \\
\hline & & & 246 & 0.088 & \\
\hline & & & 248 & 0.015 & \\
\hline & & & 250 & 0.250 & \\
\hline & & & 254 & 0.118 & \\
\hline \multirow[t]{6}{*}{ TGLA126 } & \multirow[t]{6}{*}{6} & \multirow[t]{6}{*}{$114-124$} & 114 & 0.375 & \multirow[t]{6}{*}{0.438} \\
\hline & & & 116 & 0.438 & \\
\hline & & & 118 & 0.109 & \\
\hline & & & 120 & 0.031 & \\
\hline & & & 122 & 0.016 & \\
\hline & & & 124 & 0.031 & \\
\hline \multirow[t]{4}{*}{ TGLA122 } & \multirow[t]{4}{*}{9} & \multirow[t]{4}{*}{$138-162$} & 138 & 0.045 & \multirow[t]{4}{*}{0.424} \\
\hline & & & 140 & 0.212 & \\
\hline & & & 144 & 0.030 & \\
\hline & & & 146 & 0.030 & \\
\hline
\end{tabular}




\begin{tabular}{|c|c|c|c|c|c|}
\hline \multicolumn{6}{|c|}{ Cont. Table 1.} \\
\hline \multirow{5}{*}{$\begin{array}{c}\text { TGLA122 } \\
\text { (cont.) }\end{array}$} & & & 150 & 0.424 & \\
\hline & & & 152 & 0.182 & \\
\hline & & & 154 & 0.015 & \\
\hline & & & 156 & 0.015 & \\
\hline & & & 162 & 0.045 & \\
\hline \multirow[t]{11}{*}{ INRA23 } & \multirow[t]{11}{*}{11} & \multirow[t]{11}{*}{$198-220$} & 198 & 0.106 & \multirow[t]{11}{*}{0.167} \\
\hline & & & 200 & 0.045 & \\
\hline & & & 202 & 0.030 & \\
\hline & & & 204 & 0.076 & \\
\hline & & & 206 & 0.121 & \\
\hline & & & 208 & 0.167 & \\
\hline & & & 210 & 0.106 & \\
\hline & & & 212 & 0.152 & \\
\hline & & & 214 & 0.167 & \\
\hline & & & 218 & 0.015 & \\
\hline & & & 220 & 0.015 & \\
\hline \multirow[t]{6}{*}{ ETH3 } & \multirow[t]{6}{*}{6} & \multirow[t]{6}{*}{$112-124$} & 112 & 0.288 & \multirow[t]{6}{*}{0.288} \\
\hline & & & 114 & 0.227 & \\
\hline & & & 116 & 0.015 & \\
\hline & & & 120 & 0.091 & \\
\hline & & & 122 & 0.152 & \\
\hline & & & 124 & 0.227 & \\
\hline \multirow[t]{7}{*}{ ETH225 } & \multirow[t]{7}{*}{7} & \multirow[t]{7}{*}{$134-150$} & 134 & 0.197 & \multirow[t]{7}{*}{0.452} \\
\hline & & & 138 & 0.061 & \\
\hline & & & 140 & 0.045 & \\
\hline & & & 142 & 0.121 & \\
\hline & & & 144 & 0.452 & \\
\hline & & & 146 & 0.045 & \\
\hline & & & 150 & 0.079 & \\
\hline \multirow[t]{6}{*}{ BM1824 } & \multirow[t]{6}{*}{6} & \multirow[t]{6}{*}{$176-190$} & 176 & 0.015 & \multirow[t]{6}{*}{0.364} \\
\hline & & & 178 & 0.212 & \\
\hline & & & 180 & 0.136 & \\
\hline & & & 182 & 0.364 & \\
\hline & & & 188 & 0.242 & \\
\hline & & & 190 & 0.030 & \\
\hline Mean & 8.364 & & & & 0.372 \\
\hline
\end{tabular}

$\mathrm{n}_{\mathrm{A}}$, number of alleles;

FNA, frequency of the most frequent allele. 
Acta Veterinaria (Beograd), Vol. 59. No. 5-6, 621-631, 2009.

Stevanović Jevrosima et al.: Microsatellite DNA polymorphism and

its usefulness for pedigree verification in Simmental cattle from Serbia

Table 2. Summary of heterozygosities, polymorphism information content values, power of discrimination and power of exclusion in the Serbian population of Simmental cattle

\begin{tabular}{|l|c|c|l|c|c|c|}
\hline $\begin{array}{c}\text { Microsatellite } \\
\text { marker }\end{array}$ & Ho & He & $p$ & PIC & PD & PE \\
\hline \hline TGLA227 & 0.733 & 0.851 & $0.00324^{*}$ & 0.82 & 0.922 & 0.552 \\
\hline BM2113 & 0.716 & 0.814 & 0.05005 & 0.84 & 0.920 & 0.387 \\
\hline TGLA53 & 0.656 & 0.893 & $0.00000^{*}$ & 0.88 & 0.939 & 0.393 \\
\hline ETH10 & 0.522 & 0.557 & 0.13205 & 0.58 & 0.755 & 0.246 \\
\hline SPS115 & 0.719 & 0.656 & 0.78688 & 0.60 & 0.806 & 0.485 \\
\hline TGLA126 & 0.667 & 0.654 & 0.95571 & 0.59 & 0.818 & 0.409 \\
\hline TGLA122 & 0.452 & 0.728 & $0.00163^{*}$ & 0.70 & 0.865 & 0.175 \\
\hline INRA23 & 0.774 & 0.889 & 0.26167 & 0.86 & 0.953 & 0.472 \\
\hline ETH3 & 0.742 & 0.793 & 0.29764 & 0.75 & 0.900 & 0.424 \\
\hline ETH225 & 0.594 & 0.686 & 0.05124 & 0.68 & 0.838 & 0.322 \\
\hline BM1824 & 0.710 & 0.760 & 0.65137 & 0.70 & 0.880 & 0.472 \\
\hline Mean & 0.662 & 0.753 & & 0.73 & CPD $=0.999$ & CPE $=0.999$ \\
\hline
\end{tabular}

Ho - observed heterozygosity; He - expected heterozygosity; ${ }^{\star} \mathrm{p}<0.05$; PIC - polymorphism information content; PD - power of discrimination, CPD - combined power of discrimination; PE power of exclusion; CPE - combined power of exclusion

\section{DISCUSSION}

The polymorphism of 11 microsatellite markers from ISAG panel (TGLA227, BM2113, TGLA53, ETH10, SPS115, TGLA126, TGLA122, INRA23, ETH3, ETH225, BM1824) was analysed in order to evaluate their usefulness for pedigree verification in the population of Simmental cattle in Serbia. Such investigations are necessary in most livestock breeds, because pedigree verification based on microsatellite markers is an indispensable step in both, conservation and selection programs. In cattle breeding the extensive application of artificial insemination (Al) causes the increase of pedigree errors. Incorrect paternity recording due to multiple inseminations by different sires could explain, at most, $20 \%$ of the paternity mistakes (Weller et al., 2004), but there are other factors affecting incorrect paternity assignment 1) mistakes by Al institutes in labeling semen; 2) mistakes by Al technicians in identifying semen straws; 3 ) the insemination of cows already pregnant by a previous insemination; 4) errors in entering the bull's herdbook number or name into the insemination record; 5) the use of natural-service bulls leading to pregnancies of previously inseminated cows which were assumed to be pregnant from the Al bull; 6) mistakes in sire identification when a cow enters the milking herd in schemes where pedigree information on milk records is obtained through the milk recording program; and 7) interchange of calves at birth (Christensen et al., 1982). 
The use of highly polymorphic microsatellite loci and multiplex PCR for their amplification, as well as automated genotype analysis in DNA sequencers give an almost $100 \%$ probability of parentage exclusion and ensure that the obtained results are repeatable (Radko, 2008). Paternity or parentage testing effectiveness closely depends on the level of informativeness provided by the markers (Rehout et al., 2006). The microsatellites are considered highly polymorphic, highly informative and effective in parentage testing if they exert high $\mathrm{n}_{\mathrm{A}}, \mathrm{FNA}<0.5$, high $\mathrm{He}, \mathrm{PIC}, \mathrm{PD}$ and PE (>0.5), and CPD and CPE >0.999.

The results of microsatellite marker polymorphism observed in Simmental cattle analysed in this study, are shown in Tables 1 and 2. Overall, microsatellite DNA markers analysed in the Serbian population of Simmental cattle in this study appeared more polymorphic than in other breeds of Simmental cattle (from Poland, Slovakia, Czech Republic) (Janik et al., 2001; Choroszy et al., 2006; Czerneková et al., 2006). The mean $\mathrm{n}_{\mathrm{A}}$ per locus observed in Serbian population of Simmental cattle in our study (8.364) is higher than 7.90 found in Czech Pied and 7.45 found in Slovakian Pied (Czerneková et al., 2006) or 7.27 found in Simmental cattle from Poland (Choroszy et al., 2006). Moreover, the total number of alleles we observed in Serbian population of Simmental cattle (92) is higher than Janik et al. (2001) and Choroszy et al. (2006) found in Simmental cattle from Poland for the same set of microsatellite loci ( 79 and 80 , respectively). PIC values for 11 evaluated loci in the Serbian population of Simmental cattle ranged from 0.58 to 0.88 , with the mean PIC value of 0.73 , which is comparable with the results obtained for the same set of microsatellite loci in other Simmental breeds: mean PIC value was 0.757 in Czech Pied cattle, 0.642 in Slovakian Pied cattle (Czerneková et al., 2006) and 0.641 in Simmental cattle from Poland (Choroszy et al., 2006). In Simmental cattle from Serbia, He ranged from 0.557 (ETH10, 7 alleles) to 0.893 (TGLA53, 14 alleles), with average value of 0.753 , which is comparable with values found in Slovakian Pied (0.650) and Czech Pied (0.764) in the study of Czerneková et al. (2006).

Among the 11 microsatellite loci tested in our study, four loci emerged as most polymorphic: TGLA53 ( 14 alleles, $\mathrm{PIC}=0.88, \mathrm{FNA}=0.235$ ), TGLA227 (11 alleles, $\mathrm{PIC}=0.82, \mathrm{FNA}=0.274$ ), INRA23 ( 11 alleles, $\mathrm{PIC}=0.86, \mathrm{FNA}=0.167$ ) and BM2113 (9 alleles, PIC $=0.84, F N A=0.330$ ). The loci that appeared most informative in Simmental cattle from Serbia in our study (TGLA53, TGLA227, INRA23 and BM2113) were also highly polymorphic in Simmental cattle from Poland (Janik et al., 2001; Choroszy et al., 2006). High polymorphism at the TGLA53 locus was also reported by Heyen et al. (1997) in American Simmentals. Two loci (ETH10 and SPS115) appeared less informative as FNA of these loci is higher than 0.5 ( 0.600 and 0.515 , respectively), which is accordance with the FNA values observed for the same loci in the Simmental cattle from Poland (Choroszy et al., 2006). However, the PIC values of both loci are higher than 0.5 in our study so they contribute to the overall informativeness of the whole set of tested markers. In addition, CPD for the whole set of 11 tested markers was 0.999, which is the required level of discrimination in parentage analysis (Vankan and Faddy, 1999; Pérez-Miranda et al., 2005). The CPE, which is the exclusion probability considering all 11 ISAG markers, was greater than 0.999 , indicating that these loci 
are appropriate to determine parentage in studied cattle beyond any reasonable doubt. These results indicate that whole set of 11 ISAG microsatellite markers is useful for paternity testing and pedigree verification in the studied cattle population.

The means for $\mathrm{n}_{\mathrm{A}}$ and $\mathrm{He}$ (Tables 1 and 2) indicate high levels of genetic diverisity in the population studied as found in other Simmental breeds of cattle (Janik et al., 2001; Choroszy et al., 2006; Czerneková et al., 2006). The observed deviations from Hardy-Weinberg equilibrium at three loci (TGLA227, TGLA53 and TGLA122) could be a result of the specific selection programs or caused by high polymorphism at the same loci investigated.

In conclusion, the polymorphism of 11 microsatellite markers observed in this study indicate its usefulness for paternity testing and pedigree verification in Simmental cattle from Serbia.

\section{ACKNOWLEDGEMENTS:}

This study was supported by the Ministry of Science and Technological Development of the Republic of Serbia (Grant No. 143022 and Grant No. 20011).

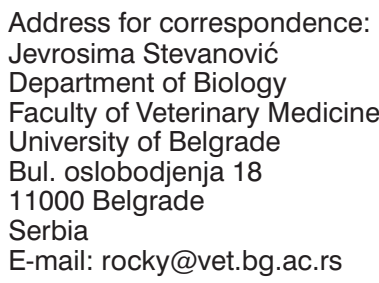

\section{REFERENCES}

1. Bovenhuis $H$, van Arendonk JAM, 1991, Estimation of milk protein gene frequencies in crossbred cattle with maximum likelihood, J Dairy Sci, 74, 2728-36.

2. Carolino I, Sousa CO, Ferreira S, Carolino N, Silva FS, Gama LT, 2009, Implementation of a parentage control system in Portuguese beef-cattle with a panel of microsatellite markers, Genet Mol Biol, 32, 306-11.

3. Cervini M, Henrique-Silva F, Mortari N, Matheucci E Jr, 2006, Genetic variability of 10 microsatellite markers in the characterization of Brazilian Nellore cattle (Bos indicus), Genet Mol Biol, 29, 48690.

4. Choroszy B, Janik A, Choroszy Z, Zabek T, 2006, Polymorphism of selected microsatellite DNA sequences in Simmental cattle chosen for identification of QTLs for meat traits, Anim Sci Pap Rep, 24, Suppl. 2, 71-7.

5. Christensen LG, Madsen P, Petersen J, 1982, The influence of incorrect sire identification on the estimates of genetic parameters and breeding values, Proc. 2nd World Congr Genet Appl Livest Prod, Madrid, Spain, 7, 200-8.

6. Curi RA, Lopes $C R, 2002$, Evaluation of nine microsatellite loci and misidentification paternity frequency in a population of Gyr breed bovines, Braz J Vet Res Anim Sci, 39, 129-35.

7. Czerneková V, Kott T, Dudková Z, Sztankóová A, Soldát J, 2006, Genetic diversity between seven Central European cattle breeds as revealed by microsatellite analysis, Czech J Anim Sci, 51, 17.

8. Čitek J, Rehout V, 2001, Evaluation of the genetic diversity in cattle using microsatellites and protein markers, Czech J Anim Sci, 46, 393-400. 
9. Čítek J, Panicke L, Rehout V, Procházková $H, 2006$, Study of genetic distances between cattle breeds of Central Europe, Czech J Anim Sci, 51, 429-36.

10. Excoffier L, Laval G, Schneider S, 2006, Arlequin ver 3.1 user manual. (http://cmpg.unibe.ch/software/arlequin3)

11. Grzybowski G, Prusak B, 2004a, Genetic variation in nine European cattle breeds as determined on the basis of microsatellite markers. II. Gene migration and genetic distance, Anim Sci Pap Rep, 22, 37-44.

12. Grzybowski G, Prusak B, 2004b, Genetic variation in nine European cattle breeds as determined on the basis of microsatellite markers. III. Genetic integrity of the Polish Red cattle included in the breeds preservation programme, Anim Sci Pap Rep, 22, 45-56.

13. Heyen DW, Beever JE, Da Y, Evert RE, Gren C, Bates SR, Ziegle JS, Lewin HA, 1997, Exclusion probabilities of 22 bovine microsatellite markers in fluorescent multiplexes for semiautomated parentage testing, Anim Genet, 28, 21-7.

14. ISAG Conference, 2008, Amsterdam, The Netherlands. Cattle Molecular Markers and Parentage Testing Workshop (http://www.isag.org.uk/ISAG/all/ISAG2008_CattleParentage.pdf

15. Janik A, Zabek T, Radko A, Natonek M, 2001, Evaluation of polymorphism at 11 microsatellite loci in Simmental cattle raised in Poland, Ann Anim Sci, 1, 19-29.

16. Ozkan E, Soysal MI, Ozder M, Koban E, Sahin O, Togan I, 2009, Evaluation of parentage testing in the Turkish Holstein population based on 12 microsatellite loci, Livest Sci, 124, 101-6.

17. Pérez-Miranda AM, Alfonso-Sánchez MA, Peña JA, De Pancorbo MM, Herrera RJ, 2005, Genetic polymorphisms at 13 STR loci in autochthonous Basques from the province of Alava (Spain), Legal Med, 7, 58-61.

18. Power Stats V12.xls software. Free program distributed by Promega Corporation, USA. From http://www.promega.com/techserv/apps/hmnid.

19. Radko A, Zyga A, Zabek T, Slota E, 2005, Genetic variability among Polish Red, Hereford and Holstein-Friesian cattle raised in Poland based on analysis of microsatellite DNA sequences, $J$ App/ Genet, 46, 89-91.

20. Radko A, 2008, Microsatellite DNA polymorphism and its usefulness for pedigree verification of cattle raised in Poland, Ann Anim Sci, 8, 311-21.

21. Rehout V, Hradecká E, Čítek J, 2006, Evaluation of parentage testing in the Czech population of Holstein cattle, Czech J Anim Sci, 51, 503-9.

22. Ron M, Blanc Y, Band M, Ezra E, Weller JI, 1996, Misidentification rate in the Israeli dairy cattle population and its implications for genetic improvement, J Dairy Sci, 79, 676-81.

23. Soldatović B, Vučinić Marijana, Stanimirović Z, Djokić D, Vučićević Marijana, 1993, A mosaicism with karyotype designation of 59.XO/60, XX/61,XXX in red pied heifer (part III), Acta Vet (Belgrade), 43, 5-6, 335-40.

24. Soldatović B, Stanimirović Z, Vučinić Marijana, Djokić D, Vučićević Marijana, 1994a, Robertsonian fusion in a simmental cow-bull mother (part II), Acta Vet (Belgrade), 44, 2-3, 173-8.

25. Soldatović B, Vučinić Marijana, Stanimirović Z, Đokić D, Vučićević Marijana, 1994b, The aberrant karyotype of a bull with characteristic of Klinefelter's syndrome (part I), Acta Vet (Belgrade), 44,1, 33-6.

26. Tian $F$, Sun $D$, Zhang $Y, 2008$, Establishment of paternity testing system using microsatellite markers in Chinese Holstein, $J$ Genet Genomics, 35, 279-84.

27. Vankan DM, Faddy MJ, 1999, Estimations of the efficacy and reliability of paternity assignments from DNA microsatellite analysis of multiple-sire matings, Anim Genet, 30, 355-61.

28. Vučinić Marijana, Soldatović B, Stanimirović Z, 1996, Robertsonian translocation T1/29 in the bovine karyotype, Strategia and Veterinary Faculty, University of Belgrade, pp 1-163 (in Serbian).

29. Weller Jl, Feldmesser E, Golik M, Tager-Cohen I, Domochovsky R, Alus O, Ezra E, Ron M, 2004, Factors affecting incorrect paternity assignment in the Israeli Holstein population, J Dairy Sci, 87, 2627-40. 
Acta Veterinaria (Beograd), Vol. 59. No. 5-6, 621-631, 2009.

30. Zaton-Dobrowolska M, Čitek J, Filistowicz A, Rehout V, Szulc T, 2007, Genetic distance between the Polish Red, Czech Red and German Red cattle estimated based on selected loci of protein coding genes and DNA microsatellite sequences, Anim Sci Pap Rep, 25, 45-54.

31. Zhou GL, Jin HG, Zhu Q, Guo SL, Wu YH, 2005, Genetic diversity analysis of five cattle breeds native to China using microsatellites, $J$ Genet, 84, 77-80.

\title{
POLIMORFIZAM DNK MIKROSATELITA I MOGUĆNOST NIJIHOVE PRIMENE U VERIFIKACIJI PEDIGREA SIMENTALSKIH GOVEDA U SRBIJI
}

\author{
STEVANOVIĆ JEVROSIMA, STANIMIROVIĆ Z, DIMITRIJEVIĆ V, STOJIĆ V, \\ FRATRIĆ NATALIJA i LAZAREVIĆ M
}

\section{SADRŽAJ}

U ovom radu analiziran je polimorfizam 11 mikrosatelitskih DNK markera (TGLA227, BM2113, TGLA53, ETH10, SPS115, TGLA126, TGLA122, INRA23, ETH3, ETH225, BM1824) u cilju procene upotrebljivosti tih markera u verifikaciji pedigrea Simentalskih goveda u Srbiji. Analizirano je ukupno 86 grla. Genomska DNK je izolovana iz sperme i krvi. Za amplifikaciju je primenjen multiplex PCR korišćenjem prajmera komercijalnog seta "StockMarks for Cattle ${ }^{\circledR}$ Bovine Genotyping Kit". Pri analizi rezultata korišćena je tehnologija automatizovanog određivanja veličine DNA fragmenata. Ukupan broj detektovanih alela bio je 92 . Srednja vrednost broja alela $\left(n_{A}\right)$ po lokusu iznosila je 8,364 , srednja vrednost sadržaja polimorfne informacije (PIC) bila je 0,73 , dok je učestalosti najčešćeg alela (FNA) u proseku iznosila 0,372. Najveća polimorfnost uočena je kod lokusa TGLA53 (14 alela, $\mathrm{PIC}=0,88$, FNA=0,235), TGLA227 (11 alela, $\mathrm{PIC}=0,82, \mathrm{FNA}=0,274)$, INRA23 (11 alela, PIC=0,86, FNA=0,167), BM2113 (9 alela, PIC=0,84, FNA= $0,330)$. Moć diskriminacije i moć isključenja celog seta proučavanih markera iznosila je 0,999. Polimorfizam uočen kod 11 mikrosatelitskih DNK markera u ovom radu ukazuje na mogućnost njihove primene u testiranju očinstva i verifikaciji pedigrea Simentalskih goveda u Srbiji. 